\title{
COMPARATIVE-HISTORICAL AND CULTURAL ANALYSIS OF EASTERN BLACK SEA REGION PEOPLE'S INTERACTION
}

\author{
Yulia A. Petrova, Maxim V. Yarovoy \\ Rostov state university of economics. Rostov-on-Don, Russian Federation \\ science-almanac@mail.ru
}

The Eastern Black sea region has been developing independently for more than four centuries, within this period the culture of this territory has changed, that has led to a change in intercultural interaction. In today's globally competitive and more peaceful condition of existence, there is a need for constructive dialogue between neighbors, which leads to the need for a better understanding of each of the parties. Comparative culturology can help to determine the differences and common points of contact of the peoples of the eastern Black Sea region, which will open the door for deep, lasting and long-term relations between the cultures and people of Georgia, Abkhazia and the Krasnodar territory of Russia. The aim of the study is to reveal the cultural background on the basis of which these people can interact and determine if there are positive prospects for joint interaction in various spheres of culture. To achieve these goals, several research steps have been carried out, in particular, they include: the definition of comparative study as a term and as a scientific basis for research; comparison of the declared cultures from a non-verbal point of view; providing data on the multilateral distribution of languages in neighboring areas; analysis of the traditional aspect of cultures of Georgia, Abkhazia and the Krasnodar territory of Russia. The final part of the study shows promising results on today's and future cultural interaction in the region of the eastern coast of the Black Sea.

Key words: comparative culturology, eastern coast of the Black Sea, culture, communication, Georgia, Abkhazia, Krasnodar territory of Russia.

[Петрова Ю.А., Яровой М.В. Сравнительно-исторический и культурологический анализ взаимодействия народов восточного Причерноморья]

Восточно-Черноморский регион развивается самостоятельно более четверти века, за это время культуры этой территории изменились, что привело к изменению межкультурного взаимодействия. В современном глобально конкурентном и более мирном условии существования появляется потребность в конструктивном диалоге между соседями, что приводит к необходимости лучшего понимания каждой из сторон. Сравнительная культурология может помочь определить различия и общие точки соприкосновения народов восточного Причерноморья, что откроет двери для глубоких, прочных и долгосрочных отношений культур и людей Грузии, Абхазии и Краснодарского края России. Целью данного исследования является раскрытие культурного базиса, на основе которого эти люди могут взаимодействовать и определение, существуют ли положительные перспективы совместного взаимодействия в различных сфрерах культуры. Для достижения этих целей было проделано несколько исследовательских шагов, в частности, к ним относятся: определение компаративистики как термина и как научной основы исследования; сравнение заявленных культур с невербальной точки зрения; предоставлении данных о многостороннем распространении языков в соседствующих районах; анализ традиционного аспекта культур Грузии, Абхазии и Краснодарского края России. В заключительной части исследования показаны многообещающие результаты о сегодняшнем и будущем культурном взаимодействии в районе восточного побережья Черного моря.

Ключевые слова: сравнительная культурология, восточное побережье Черного моря, культуры, коммуникация, Грузия, Абхазия, Краснодарский край России.

Yulia A. Petrova - candidate of philosophy, associate professor. Rostov state university of economics. Rostov-on-Don, Russian Federation. 
Maxim V. Yarovoy - student. Rostov state university of economics. Rostov-on-Don, RussianFederation.

ПетроваЮлияАндреевна - кандидатфилософрскихнаук, доцент. Ростовский государственный экономический университет. г. Ростов-на-Дону, Россия.

Яровой Максим Владимирович - студент. Ростовский государственный экономический универcumem. е. Ростов-на-Дону, Россия.

One of the latest trends in modern cultural studies is comparative culturology or comparativistics. Many relevant disciplines are aimed at studying the problems of the typology of culture, the unification of culture, followed by multiculturalism. The emphasis is also placed on comparison, collation and isolation of similar and different features of communities of people living in adjacent territories, in particular in the eastern Black Sea region, which consists of Georgia, Abkhazia and part of the Krasnodar Territory of Russia within the Black Sea coastline. However, from small scales, the analysis extends to the comparison of global cultures, in particular it is study of the parallels between the Caucasian and Eastern European cultures, a deeper analysis of the problems of interethnic interaction in the large Black Sea region. Also, there are attempts to examine the influence of the Georgian and Abkhaz cultures on each other and on the culture of the south of Russia, in addition there are attempts to study the continuous process of interweaving, transforming and the emergence of new ties between cultures under the influence of both global trends and specific regional facts of the interaction of these cultures and the communities that formed them. Modern researches on topic help to answer questions as of global importance (such as leadership, correlation of world, regional cultures and cultures of individual countries) [1, p. 2], and local, which contributes to a better understanding of the development of intercultural relations of the eastern Black Sea coast from the theoretical point of view, as well as the practical implementation of federal, regional and local policies in the Krasnodar Territory, the level of international relations between Russia, Georgia and Abkhazia and with this intergovernmental interaction.

In this article, we summarize the similarities and differences in the cultures of the ethnoses inhabiting the region of the eastern Black Sea coast, or, as it is otherwise called, the Black Sea coast of the Caucasus, to which the coastal regions of Georgia, the Krasnodar Territory in Russia, and Abkhazia are generally attributed.

Turning directly to the indicated comparative analysis, it is worthwhile to say that the basis of interpersonal and intercultural interaction is communication, thus the main directions considered as distinctive socio-cultural parameters that will be given in the article are:

- linguocultural;

- non-verbal (proxemics, visual contact, etc.).

In addition, it is important to take into account the cultural and historical context of the development of the ethnoses of the designated region, including traditions, customs, historical past of nations, in short, those factors that have led the Black Sea culture to the current state, and which inevitably determine the future shape of cultures themselves, and relationships with neighbors.

The first part of the paper is aimed on studying communication, it is worth saying that communication in itself is an integral part of people's daily activities, because one of the most important needs is the need for communication - interpersonal and intergroup interaction with the exchange of information and certain results of mental activity (thoughts, feelings, estimates, etc.). In terms of its material expression, communication consist of two forms: verbal andnon-verbal. 
Non-verbal communication is a system of signs used in the process of communication, different from linguistic means, having various forms of manifestation. And although the language channels of communication have primary importance, in no case one should ignore non-verbal means of communication. Scientific researches prove that from 40 to $80 \%$ of communication occurs in non-verbal area. And $55 \%$ of messages are perceived through facial expressions, posture, gestures, and $38 \%$ through intonation and voice modulation [5], an American researcher and one of the founders of kinesics (the science of non-verbal communication through facial expressions and gestures), Ray Berdvistel cited an estimate that only $35 \%$ of all information transmitted through interpersonal interaction is verbal, $65 \%$, respectively, is not transmitted by words [2]. It was also Berdvistel who first applied structural and linguistic methods to the analysis of non-verbal communication. Subsequently, on the basis of his work, features of nonverbal behavior of people belonging to one or another ethnos were described; specific sociocultural peculiarities characteristic of certain communities of people were singled out. Further studies by P. Ekman and W. Friesen have shown that there are concrete and definite differences in the facial expressions of people belonging to different cultures, and that there are universal patterns of cultural behavior [3].

As for the peculiarities of non-verbal interaction of the people of the eastern Black Sea region, we emphasize that the traditions and customs of the people of the Caucasus differ significantly from the way of life of the inhabitants of the Krasnodar Territory of Russia. Ethnic specificity also manifests itself in terms of $t$ proxemics, which was defined by Edward Hall, its founder, as interrelated observations and theories of human use of space as a specialized elaboration of culture [4]. This aspect will be the starting pointof the research of differences between stated ethnoses and nations.

Caucasian cultures, in particular the cultures of Georgia and Abkhazia, are strongly influenced by traditions, which are a great help for the proxemic features. The first thing that happens when two people meet is a greeting, in every culture a great importance is given to this event, so it is also actual for the countries of the Caucasus region, especially Georgia, where the greeting ritual is very important. No matter how the society changes over time, the cultural heritage of Georgia remains - and the more traditions remain in daily use, the more noticeable are the differences between everyday life of the residents of the Krasnodar Territory and Georgia. Caucasian rules of conduct seem to the Russians cumbersome and complicated, but it must be borne in mind that they have been formed for centuries as manifestations of one's own dignity and were created to prevent conflicts.

In Georgia, the greeting is built in such a way as to show respect to the interlocutor and in no case to cause an occasional resentment. A mandatory greeting in Georgia and throughout the Caucasus region is a handshake. It is a symbol of recognition in the interlocutor of a respected and worthy person, demonstration of trust and expression of one's honor. Not shaking the outstretched hand means to inflict the most serious insult and demonstrate deep dislike. The youngest always come closer to older for greeting and gives his hand first, then take a step back. Traditions require keeping a distance between the interlocutors - about a meter in the case of two men, two meters for a man and a woman and about seventy centimeters for a conversation between women. If the greeting takes place in the room where interlocutors were sitting before, they greet the newcomer standing up, showing him their respect. Georgians say at the meeting "I wish to win!" - this is a greeting that had been passed from generation to generation by men, it means characterization of a person as a worthy and glorious warrior. If the meeting takes place on the street, the Georgians greet people by raising their hands to the head, 
but in no case removing the headgear, because it is for the residents of Georgia a symbol of human dignity, therefore removing it, Georgian would show contempt for himself.

The rules of etiquette are different for men to communicate with each other and with women. In Georgia, women never give a hand to a man and do not touch him with a greeting - the only exception can be a greeting between relatives. Kisses on the cheek when meeting are either inadmissible. By tradition, without allowing any contact with men, a woman defends her honor and honor of her family. If, at a meeting, a man passes by a woman, he must leave her on his right hand. If a woman passes by a seating friend, his task is to rise and greet her, but she should not approach him too close. These conventions are associated primarily with the status of a woman in a society that, on the one hand, is traditionally lower than that of a man, and on the other, the higher the more worthy a woman leads herself.

As for the Russian people, the classical study of the proxemic zones, that was made by psycholinguist A.A. Leontief gave the following results. Personal distance (casual conversation in a home setting) for sitting people is on the average $120 \mathrm{~cm}$. This distance decreases noticeably in communication between young women (interval 55$100 \mathrm{~cm})$ and increases between young and elderly women $(125-230 \mathrm{~cm})$, and between men of all ages the same, approximately $70-156 \mathrm{~cm}$ [12, p. 215]. For most residents of the Krasnodar Territory of Russia, ageneral greeting is a handshake (an exchange of handshakes). The closer the relations of partners, the longer the hand lingers. A quick snatch of the hand is perceived as a tactlessness or as a fear of another person. According to the etiquette, the handshake is done with the whole hand. It is impolite as an overly strong and too weak handshake. A greeting with a glance is also common, when people who are relatively far from each other can close their eyes for a second or nod their heads [7].

The attempt to determine the social distance did not lead to any convincing result, since a huge spread (from 30 to $840 \mathrm{~cm}$ ) was found. It was only recorded that once accepted distance between communicants in the future does not change. In general, it seems that in the Russian community the system of zones is not so stable and depends more on various non-spatial but situational factors.

Thus, it can be noted that, despite the differences in the cultures of the eastern Black Sea coast, some elements, such as the handshake of men, are present in all ethnic groups.

The next factor that should be taken into account when analyzing the cultures of the eastern Black Sea region is a language that can be considered as a product and instrument of culture through which cultural heritage is produced, accumulated and broadcasted [10].

The official national language of Georgia is the Georgian, it forms the basis of office work, literature, music and the media, while it is native to only $80 \%$ of the population of Georgia - the linguistic map of the country is quite variegated, but in the case of the Black Sea coast of the country, the Georgian language prevails. As for Abkhazia, there is Abkhazian language, which stands in a separate language group from Georgian. A total of more than 100,000 people speak Abkhazian in some regions of Georgia.

The largest minority language in Georgia is Megrelian. According only to the most conservative estimates, it is used in everyday life by more than 500 thousand people living in the western regions of Georgia and near the Black Sea coast.

Russian language in Georgia and Abkhazia is customary popular in large tourist areas, hotels and resorts, so it is the eastern Black Sea coast that becomes the place where the Russian language is most common. However, the number of Russian speakers permanently residing in Georgia is sharply reduced every year. 
As for the territory of the coastal part of the Krasnodar Territory, the absolute majority of the population communicates in Russian, but other languages are spread in ethnic groups, in particular, the Armenian language is especially widespread in the Apsheronregion, also due to its proximity to the Republic of Adygea, a small part of the population speaks the Kabardino-Cherkess language, which refers to the AbkhazAdyghe language group, which emphasizes that there are not only traditional, but also language connections of the regions of the eastern Black Sea coast, that go in both directions.

The center of culture, according to Gert Hofstede is "human values" or "value orientations." "People define values that can be interpreted in the narrow sense of the word, only by members of a particular culture" [6; 8]. Speaking about the Georgian and Abkhaz cultures, it is worth saying that their main values include family, hospitality, respect for elders, adherence to traditions. Particular attention in the general analysis of the comparison of cultures of the Black Sea Coast should be paid to the institution of hospitality, which belongs to a notable ethnocultural peculiarity of the region and is part of the traditions of everyday life, and also occupies a prominent place in the system of socio-normative culture of the people of the Caucasus [9], moreover, the important fact is that Georgians and Abkhazians are one of the most hospitable nations of the Caucasian region. This trait has been cultivated since childhood, but the guest should also understand that the abuse of hospitality of the residents of Georgia and Abkhazia is tantamount to the greatest insult. Invited guests should bring gifts for each member of the hosting family. For Georgians exchange of gifts is a ritual, and in response to a gift from a guest it is also accepted to give something. According to the old laws of Georgian etiquette, any guest has the right to live in a host's house for three days, and on the morning of the fourth day - politely ask how much he can stay on a visit. Also, Georgians do not have a clear allocation of places of honor for guests when they eat, they can be located freely according to their own preferences. Continuing the theme of food intake and, in particular, feast, it is important to note that traditionally in Georgia and Abkhazia, women and men were placed at the table separately, then in the 1990s, such sexual segregation has survived only in the rural territories, and in the city women can sit at the table along with men (except for long nighttime feasts). Turning to the topic of gender relations, it must be emphasized that a man in a traditional Georgian family is the head, the defender and the main source of family income. Women historically engaged in housekeeping and raising children, but by the twentieth century with mass emancipation, these facets began to wear off, and the process of increasing the role of women in society is evolving to this day [11].

Thus basing on the facts of peculiarities of cultures of eastern Black Sea region we can conclude that there are at the same time significant differences between people of Georgia Abkhazia and Krasnodar Territory of Russia and close similarities, including the spread of languages and common traditional and communicative details. Therefore, there is a huge potential in positive rapprochement of these cultures, which can lead to a strong and mutually beneficial union of unique and independent ethnic groups developing together, without losing their cultural identity.

\section{Лumepamypa}

1. Борзова Е.П. Сравнительная культурология. Том 1. Санкт-Петербург, 2013.

2. Волкова Л.Б. Невербальное поведение русских и японцев в сравнительном аспекте // Universum: филология и искусствоведение. 2016. № 6 (28). 
URL: http://7universum.com/ru/philology/archive/item/3298 (контрольная дата: 09/10/2017).

3. Васильева О.А. Гостеприимство как часть культурной традиции народов Северного Кавказа // Народы Северного Кавказа: история и современность. Материалы Всероссийской научно-практической конференции. Хасавюрт. 2012.

4. Леонтьев А. А. Психология общения. М., 1999.

5. Петрова Ю.А. Лингвистический и культурный взгляд на взаимосвязь между субкультурой и языком. Материалы международной научнопрактической конференции «Региональные проблемы современной миграции». Ростов-на-Дону, 28 марта 2016 года. http://sciencealmanac.ru/documents/72/2016-01-14-Petrova.pdf

6. Склярова Е.К., Камалова О.Н. Философские аспекты викторианского здравоохранения // Экономические и гуманитарные исследования регионов. 2015. №. 1.

7. Ekman P. Facial expression // Nonverbal behavior and communication. New York, 1978.

8. Hall Edward T. The hidden dimension. Doubleday, Garden City, N.Y., 1966.

9. Hofstede $G$. The business of international business is culture // International business review Vol. 3. No. 1. 1994.

10. McDermott R. Profile: Ray L. Birdwhistell. The Kinesics Report. 1980. No 2 (3).

11. Petrova Yu., Yarovoy M.Ecological and cultural identity of the peoples of the North Caucasus // НаучныйальманахстранПричерноморья.2016. № 4.

12. Sampson $E$. The image factor. L., 1994.

\section{References}

1. Borzova E.P. Comparative culturology. Vol. 1. St. Petersburg, 2013.

2. Volkova L.B. Nonverbal behavior of Russians and Japanese in a comparative aspect // Universum: Philology and art criticism. 2016. No 6 (28). URL: http://7universum.com/en/philology/archive/item/3298 (reference date: 09/10/2017).

3. Vasilyeva O.A. Hospitality as part of the cultural tradition of the peoples of the Northern Caucasus // The peoples of the North Caucasus: History and Modernity. Materials of the All-Russian Research Conference. Khasavyurt. 2012.

4. Leontiev A. A. Psychology of communication. M., 1999.

5. PetrovaYu.A. Linguistic and cultural view on the relationship between subculture and language. Materials of international science-practical conference "Regional problems of modern migration". Rostov-on-Don, March 28, 2016. http://science-almanac.ru/documents/72/2016-01-14-Petrova.pdf

6. Sklyarova E.K., Kamalova O.N. Philosophical aspects of Victorian health service // Economic and humanitarian researches of the regions. 2015. No 1.

7. Ekman P. Facial expression // Nonverbal behavior and communication. New York, 1978.

8. Hall Edward T. The hidden dimension. Doubleday, Garden City, N.Y., 1966.

9. Hofstede $G$. The business of international business is culture // International business review Vol. 3. No. 1. 1994.

10. McDermott R. Profile: Ray L. Birdwhistell. The Kinesics Report. 1980. No 2 (3).

11. Petrova Yu., Yarovoy M.Ecological and cultural identity of the peoples of the North Caucasus // Science almanac of Black Sea region countries . 2016. No 4. 
ISSN 2414-1143

Научный альманах стран Причерноморья. 2017. Том 11. № 3

12. Sampson E. The image factor. L., 1994. 